\title{
Perlindungan Terhadap Gaji Dosen Swasta Menurut Undang-Undang Nomor 14 Tahun 2005 Tentang Guru Dan Dosen
}

\section{Mila Karmila Adi}

Abstrak
The article 52 verse (3), the Teacher and Lecturer's Act Number 14 Year 2005, says that a
lecturer who works in a private institution is given a payment based on the work agreement
or collective labor agreement. It shows that the private lecturer's payment will be regulated
basically on the two party's agreement, the lecturer and the private institution. Although there
are some provisions that regulate about the payment' details from the Act, some questions
will come up in the legal protection to the private lecturer in getting good payment, for
example "how is the payment regulation based on the work agreement?", "how is the protection
to the private lecturer's payment?"

\section{Pendahuluan}

Sejak dimunculkannya rancangan Undang-úndang Guru dan Dosen ${ }^{1}$ maka.sudah cukup banyak kontroversi yang muncul. Kontroversi ini terutama tentang kesejahteraan yang menyangkut profesi Guru, sedangkan bagi profesi Dosen tidak banyak yang menyinggungnya. Namun demikian, pengaturan profesi Guru dan Dosen di dalam UU Guru dan Dosen akan menimbulkan konsekuensi yang sangat mendasar bagi profesi Guru dan Dosen.

Konsekuensi mendasar yang akan mempengaruhi profesi Guru dan Dosen ini menyangkut penegasan status Guru atau
Dosen sebagai suatu profesi yang memerlukan kualifikasi, kompetensi dan sertifikasi tertentu. Profesi Guru dan Dosen tidak hanya akan diatur berdasarkan peraturan perundangundangan, khususnya bagi Guru dan Dosen Swasta juga didasarkan pada perjanjian kerja atau kesepakatan kerja bersama.

Bagi Guru dan Dosen Negeri, yaitu yang diangkat oleh Pemerintah, munculnya UU Guru dan Dosen dianggap sebagai berkah yang memungkinkan bagi mereka untuk mendapatkan peningkatan kesejahteraan sebagaimana yang diharapkan. Sedangkan bagi Guru dan Dosen Swasta, yaitu yang

${ }^{1}$ Saat ini telah disahkan menjadi UU Nomor 14 Tahun 2005 Tentang Guru dan Dosen sejak tanggal 30 Desember 2005. Namun demikian beberapa pasalnya menunjukkan bahwa dalam beberapa hal tidak dapat langsung dilaksanakan, seperti sertifikasi paling cepat dapat diterapkan tahun 2007 mendatang karena menunggu pengaturan lebih lanjut. 
diangkat oleh satuan pendidikan yang diselenggarakan oleh masyarakat, hal ini masih banyak menimbulkan pertanyaan.

Pertanyaan-pertanyaan muncul berkaitan dengan kesejahteraan Guru dan Dosen Swasta karena UU Guru dan Dosen tersebut banyak memberikan peluang bagi satuan pendidikan yang diselenggarakan oleh masyarakat untuk mengatur tersendiri melalui perjanjian kerja atau kesepakatan kerja bersama. Hal ini menunjukkan bahwa pemberian kesejahteraan bagi Guru dan Dosen Swasta akan bergantung pada peraturan perundang-undangan dan kemampuan satuan pendidikan yang bersangkutan atas dasar tawar-menawar yang dilakukan antara dua pihak, Guru atau Dosen Swasta dan satuan pendidikan.

Pembahasan dalam tulisan ini dibatasi pada perlindungan hukum terhadap gaji dosen swasta terutama dengan adanya pengaturan dalam UU Guru dan Dosen yang memunculkan adanya perjanjian kerja atau kesepakatan kerja bersama sebagai dasar hubungan antara dosen dan satuan pendidikan tinggi.

Masalah-masalah yang akan dibahas lebih lanjut adalah bagaimana pengaturan gaji dosen swasta berdasarkan perjanjian kejja atau kesepakatan kerja bersama dan bagaimana perlindungan terhadap gaji dosen swasta berdasarkan UU Guru dan Dosen.

\section{Privatisasi Hubungan antara Dosen Swasta dan Satuan Pendidikan Tinggi melalui Perjanjian Kerja atau Kesepakatan Kerja Bersama}

Sebelum munculnya UU Guru dan Dosen, pengaturan gaji dosen baik swasta maupun negeri secara umum mengacu pada peraturan perundang-undangan. Peraturan tentang gaji dosen ini berkaitan dengan kebijakan pemerintah tentang kenaikan pangkatjjabatan akademik yang harus dilalui oleh dosen sebagai suatu jabatan fungsional.

Status dosen swasta, baik dosen tetap maupun dosen tidak tetap, selain melalui surat pengangkatan juga dapat dilakukan dengan surat perjanjian kerja yang mengikat dosen yang bersangkutan sebagai pegawai dari suatu institusi pendidikan tinggi swasta. Akan tetapi surat perjanjian kerja tersebut hanya mengatur secara umum, sedangkan detail atau rincian mengenai hak dan kewajiban para pihak mengacu pada peraturan perundang-undangan yang berlaku.

Peraturan yang berlaku di lingkungan institusi swasta pada kenyataannya mengacu pada peraturan perundang-undangan, sehingga secara tidak langsung yang berlaku selama ini adalah peraturan perundangundangan, baik untuk dosen negeri maupun swasta. Atau tegasnya aturan yang mendasari hubungan antara dosen swasta dengan satuan pendidikan tinggi selama ini berasal dari peraturan perundang-undangan.

Hubungan antara dosen swasta dan satuan pendidikan tinggi yang didasarkan pada peraturan perundang-undangan menunjukkan besarnya campur tangan negara/pemerintah terhadap para pihak dalam hubungan itu. Sedemikian besarnya campur tangan pemerintah tersebut menyebabkan seolah-olah pemerintah menjadi salah satu pelaku dalam hubungan itu, yaitu sebagai pihak ketiga, baik dalam hal pengaturan, pengawasan dan penyelesaian sengketa yang terjadi antara dua pihak, yaitu dosen dan satuan pendidikan tinggi. 
Campur tangan pemerintah ini disebut dengan freies ermessen/discretionaire, ${ }^{2}$ yaitu wewenang yang diberikan kepada pemerintah untuk mengambil tindakan guna menyelesaikan suatu masalah penting yang mendesak, yang datang secara tiba-tiba dimana belum ada peraturannya. Jadi kebijaksanaan itu diambil tanpa dilandasi oleh peraturan umum, yang memberikan kewenangan kepada administrasi negara untuk membuat kebijaksanaan tersebut.

Kebijaksanaan itu dalam praktiknya sering dituangkan dalam berbagai bentuk, seperti surat edaran, pedoman, pengumuman, surat keputusan yang bersifat abstrak dan umum bahkan dalam bentuk peraturan yang disebut pseudo-wet geving (perundangundangan semu). ${ }^{3}$

Freies Ermessen tersebut tidaklah bersifat semena-mena karena harus tetap mendasarkan diri hukum yang berlaku, baik hukum yang tertulis maupun yang tidak tertulis. Dengan demikian walaupun pada pihak administrasi negara ada wewenang yang besar untuk membuat kebijaksanaan sendiri, akan tetapi harus tetap dapat dipertanggung jawabkan dalam kerangka perlindungan terhadap hak asasi manusia.

Campur tangan dari pihak pemerintah/ administrasi negara ini semakin hari semakin meluas sehingga pembagian hukum yang bersifat privat dan publik menjadi semakin bergeser. Semakin banyak hukum privat yang mengatur hubungan antar kepentingan dalam masyarakat diatur oleh "negara" sehingga bergeser ke arah hukum publik, dengan demikian hukum publik menjadi semakin luas dan besar. Hal ini dapat dilihat dalam skema yang digambarkan oleh Crince Le Roy yang menunjukkan semakin berkembangnya Hukum Administrasi Negara ${ }_{1}^{4}$ bahkan bukti yang lebih jelas lagi adalah pergeseran beberapa bidang yang awalnya termasuk dalam hukum privat menjadi hukum publik atau termasuk dalam Hukum Administrasi Negara Khusus, yaitu Hukum Kesehatan dan Hukum Ketenagakerjaan.

Campur tangan negara/pemerintah melalui peraturan perundang-undangan dalam hubungan antara dosen dan satuan pendidikan tinggi, tanpa membedakan negeri atau swasta, menimbulkan hubungan yang bersifat publik dan lebih lanjut diatur dalam Hukum Administrasi Negara yang mendasari tindakan pemerintah itu. Dengan demikian sebelum muncuinya UU Guru dan Dosen, hubungan antara dosen dan satuan pendidikan tinggi seluruhinya tunduk pada peraturan perundang-undangan dan masuk dalam lingkup hukum publik (publiekrechtelijk).

- Khusus masalah perjanjian kerja seringkali masih menjadi perdebatan, apakah perjanjian kerja masih tunduk pada Hukum Perdata atau telah beralih di bawah Hukum Publik. Perjanjian kerja atau kesepakatan kerja bersama selama ini merupakan istilah yang dikenal dalam bidang ketenagakerjaan/ perburuhan. Kedua istilah tersebut mempunyai pengertian yang berbeda, sebagaimana diatur

${ }^{2}$ E.Utrecht, Pengantar Hukum Tata Usaha Negara Indonesia, (Jakarta: Penerbitan dan Balai Buku Indonesia, 1957), hlm.17-21.

${ }^{3}$ SF.Marbun, Peradilan Administrasi Negara dan UpayaAdministrasi di Indonesia, Yogyakarta: Liberty, 1997) him.12.

${ }^{4}$ Sri Soemantri, Bunga Rampai Hukum Tata Negara:Indonesia, (Bandung:Alumni, 1992), hlm.34. 
dalam Pasal 1 angka 14 dan angka 21 UU Nomor 13 Tahun 2003 Tentang Ketenagakerjaan.

Perjanjian kerja adalah perjanjian antara pekerja/buruh dengan pengusaha atau pemberi kerja yang memuat syarat-syarat kerja, hak dan kewajiban para pihak, sedangkan kesepakatan kerja bersama ${ }^{5}$ adalah perjanjian yang merupakan hasil perundingan antara serikat pekerja/serikat buruh atau beberapa serikat pekerja/serikat buruh yang tercatat pada instansi yang bertanggung jawab di bidang ketenagakerjaan dengan pengusaha atau beberapa pengusaha atau perkumpulan pengusaha yang memuat syarat-syarat kerja, hak dan kewajban kedua belah pihak.

Istilah perjanjian kerja ${ }^{6}$ juga telah dikenal dalam Kitab Undang-undang Hukum Perdata/ KUHPdt, dengan pengertian sebagai "suatu persetujuan bahwa pihak kesatu, yaitu buruh, mengikatkan diri untuk menyerahkan tenaganya kepada pihak lain, yaitu majikan, dengan upah selama waktu yang tertentu".?

Istilah perjanjian kerja atau kesepakatan kerja bersama yang diatur dalam UU Ketenagakerjaan maupun dalam KUHPdt menunjuk pada hubungan yang timbul antara dua pihak, yaitu pekerja/buruh dengan majikan/pengusaha. Hubungan ini disebut sebagai hubungan kerja yang melibatkan individu atau badan hukum, dan merupakan bagian dari hubungan keperdataan. Hubungan keperdataan termasuk dalam lingkup hukum perdata/privaatrechtelijk, sehingga pemerintah sebagai pihak ketiga pada dasarnya tidak terlibat dalam hubungan tersebut.

KUHPdt sendiri mengenal 3 (tiga) macam perjanjian yang termasuk dalam perjanjian untuk melakukan pekerjaan, yaitu: ${ }^{8}$

1. Perjanjian kerja, yaitu perjanjian antara pekerja/buruh dan pengusaha yang didasarkan pada suatu pekerjaan. Pekejaan inilah yang menjadi objek dan tujuan dalam perjanjian kerja, sehingga rincian mengenai jenis, waktu, cara dan sebagainya tentang pekerjaan itu dapat diatur dalam perjanjian kerja sesuai kesepakatan para pihak. Dalam perjanjian kerja ini terdapat hubungan yang mengikat satu pihak, yaitu pekerja/buruh, karena pekerja/buruh lah yang melakukan pekerjaan itu untuk kepentingan pihak pengusaha. Hal inilah yang menimbulkan suatu hubungan yang tidak sejajar/ seimbang, yaitu hubungan diperatas (dienstverhouding), yaitu pihak pekerjal buruh dalam melakukan pekerjaannya harus tunduk/taat pada perintah/petunjuk Bersama.

${ }^{5}$ Istilah kesepakatan kerja bersama dalam UU Ketenagakerjaan telah diubah menjadi Perjanjian Kerja

${ }^{8}$ Menurut pendapat Iman Soepomo, bahwa istilah yang dipakai untuk perjanjian kerja dalam KUHPdt terjemahan oleh Subekti dan Tjitrosudibio, yaitu persetujuan perburuhan, adalah kurang tepat. Lihat Iman Soepomo, Pengantar Hukum Perburuhan, Cetakan kesebelas (edisi revisi), (Jakarta:Djambatan, 1995), hlm.52.

${ }^{7}$ Pasal 1601a KUHPdt.

${ }^{8}$ Pasal 1601 KUHPdt berbunyi sebagai berikut: “Selain persetujuan untuk menyelenggarakan beberapa jasa yang diatur oleh ketentuan-ketentuan khusus untuk itu dan oleh syarat-syarat yang diperjanjikan, dan bila ketentuan-ketentuan yang syarat-syarat ini tidak ada, persetujuan yang diatur menurut kebiasaan, ada dua macam persetujuan, dengan mana pihak kesatu mengikatkan diriuntuk mengerjakan suatu pekerjaan bagi pihak lain dengan menerima upah, yakni: perjanjian kerja dan perjanjian pemborongan kerja. 
pengusaha. Dalam hubungan yang disebut sebagai hubungan kerja ini, tidak ada kebebasan bagi pekerja/buruh dalam melakukan pekerjaan. ${ }^{9}$ Subjek dari perjanjian kerja adalah pekerja/buruh dan pengusaha.

2. Perjanjian pemborongan ${ }^{10}$ yaitu perjanjian antara pemberi borongan dan penerima borongan yang didasarkan pada suatu pekerjaan. Yang menjadi tujuan dari perjanjian pemborongan pekerjaan adalah hasil/resuult dari suatu pekerjaan, sehingga yang menjadi objek dari perjanjian pemborongan pekerjaan adalah hasil pekerjaan bukan pekerjaan itu sendiri. Para pihak tidak akan mengatur mengenai rincian jenis, cara dan sebagainya tentang pekerjaan itu sendiri, namun seringkali yang menjadi patokan adalah waktu untuk selesainya pekerjaan tersebut. Para pihak mempunyai kedudukan yang seimbang, bahkan seringkali pihak pemberi borongan menyerahkan sepenuhnya kepada penerima borongan mengenai cara dan bagaimana pekerjaan itu dilakukan karena pihak penerima borongan dianggap lebih tahu atau mempunyai keahlian untuk melakukan pekerjaan. Subjek perjanjian pemborongan adalah pemberi borongan dan penerima borongan.
3. Perjanjian meiakukan pekerjaan/jasa tertentu, yaitu perjanjian yang didasarkan pada suatu usahalinspanning untuk mencapai suatu tujuan tertentu. Pekerjaan/jasa tertentu yang dilakukan oleh seorang yang disebut profesional ini diukur berdasarkan "usaha maksimal" yang dilakukan sebagai objek perjanjian, bukan mengenai pekerjaan atau hasil dari pekerjaan itu. Walaupun ada standar atau tolok ukur yang dapat diterapkan untuk menentukan bagaimana pekerjaan itu dilakukan dan kemungkinan hasil yang akan dicapai, akan tetapi pekerjaan tidak dapat dijadikan objek perjanjian ini. Subjek perjanjian melakukan pekerjaan/jasa tertentu adalah pemberi layanan dan penerima layanan, contoh dokter dan pasien," pengacara dan kliennya, notaris dan kliennya, dosen dan mahasiswanya.

Pengaturan hubungan antara dosen swasta dan pimpinan satuan pendidikan tinggi melalui perjanjian kerja atau KKB pada dasarnya merupakan privatisasi hubungan, karena sebelum UU Guru dan Dosen muncul, hubungan dosen swasta dan pimpinan satuan pendidikan tinggi sebagian besar atau bahkan seluruhnya diatur melalui peraturan perundangundangan yang menunjukkan besarnya campur tangan negara atau pemerintah.

${ }^{9}$ Sebagaimana dijelaskan oleh Iman Soepomo, bahwa buruh hanya mempunyai modal "tenaga"-nya saja, walaupun secara yuridis buruh sejajar dengan pengusaha akan tetapi secara ekonomi dan sosiologis adalah tidak bebas dan tidak sejajar dengan majikan/pengusaha. Lihat Iman Soepomo, Ibid., hlm 6-7.

${ }^{10}$ Pasal $1601 \mathrm{~b}$ KUHPdt: Perjanjian pemborongan kerja ialah suatu persetujuan bahwa pihak kesatu, yaitu pemborong, mengikatkan diri untuk menyelesaikan suatu pekerjaan bagi pihak lain, yaitu pemberi tugas, dengan harga yang telah ditentukan.

11 Perkembangan saat ini dalam bidang kedokteran muncul suatu hubungan antara dokter dan pasien yang didasarkan pada suatu hasil/resuult, karena ada tindakan-tindakan medis, contoh operasi kecantikan, yang menjanjikan suatu hasil tertentu. Lihat juga Fred Ameln, Kapita Selekta Hukum Kedokteran, Cetakan Pertama, (Jakarta: Grafikatama Jaya, 1991), hlm.43. 
Dengan berkurangnya campur tangan negara/pemerintah tersebut, maka kesepakatan antara kedua belah pihak, baik dosen swasta maupun satuan pendidikan tinggi, merupakan hukum yang mengikat sebagai undang-undang bagi mereka. Kalau demikian halnya, maka kekuatan tawar-menawar antara kedua belah pihak akan sangat menentukan dalam pembuatan perjanjian.

Kekuatan tawar-menawar yang mendasari hubungan antara dosen swasta dan institusi yang bersangkutan dapat dipengaruhi oleh berbagai faktor, baik internal maupun eksternal. Faktor-faktor internal merupakan faktor yang muncul dari kedua belah pihak, antara lain adalah kebutuhan, kepentingan, kemampuan dan keinginan para pihak.

Faktor-faktor eksternal yang dapat mempengaruhi kekuatan tawar-menawar para pihak, antara lain adalah kekuatan pasar kerja; angkatan kerja, peraturan perundangundangan, kondisi sosial, ekonomi, politik maupun budaya.

Faktor-faktor internal maupun eksternal dalam hubungan dua pihak akan menentukan kesepakatan yang dicapai oleh para pihak. Apabila para pihak mempunyai kekuatan tawarmenawar yang seimbang, maka kesepakatan yang diperoleh akan menguntungkan kedua pihak. Akan tetapi apabila kekuatan tawarmenawar para pihak tidak seimbang, maka kesepakatan yang dicapai akan merugikan salah satu pihak dan menguntungkan pihak lain.

Dari aspek hukum perdata, maka Pasal 1320 KUHPdt menyatakan bahwa untuk sahnya perjanjian diperlukan empat syarat:

1. Sepakat mereka yang mengikatkan dirinya;
2. Kecakapan untuk membuat suatu perikatan;

3. Suatu hal tertentu;

4. Suatu sebab yang halal.

Kesepakatan sebagai salah satu syarat utama dalam suatu perjanjian dari aspek hukum perdata merupakan unsur yang melekat pada subjek perjanjian (unsur subjektif), selain adanya unsur kedewasaan/ kecakapan. Kesepakatan yang melekat pada pihak pembuat perjanjian akan sangat tergantung pada kondisi para pihak. Walaupun demikian dalam hukum perdata yang diatur dalam KUHPdt juga menyatakan bahwa unsur kesepakatan tidak boleh didasari oleh paksaan, penipuan atau kekhilafan dari para pihak. ${ }^{12}$

Pasal 1338 KUHPdt menyebutkan bahwa semua perjanjian yang dibuat secara sah berlaku sebagai undang-undang bagi mereka yang membuatnya. Perjanjian itu tidak bisa ditarik kembali selain dengan sepakat kedua belah pihak atau alasan-alasan yang oleh undang-undang dinyatakan cukup untuk itu. Perjanjian juga harus dilakukan dengan itikad baik.

Secara keperdataan, kedua pihak terikat kuat oleh perjanjian yang dibuat, namun demikian perjanjian yang dibuat oleh para pihak haruslah memenuhi syarat objektif yang melekat pada objek perjanjian itu, yaitu hal tertentu dan suatu sebab yang halal.

Hal tertentu berarti adalah adanya kejelasan dari objek perjanjian, baik dari segi jenis, jumlah, mutu, dan sebagainya. Objek perjanjian juga harus didasarkan pada sebab/ kausa yang halal, yaitu tidak boleh bertentangan dengan Undang-undang/UU,

\section{${ }^{12}$ Pasall 1321 KUHPdt.}


kesusilaan dan ketertiban umum. ${ }^{13}$ Dengan demikian objek perjanjian tidak boleh menyimpangi ketentuan-ketentuan yang ada dalam UU apabila ada UU yang terkait dengan objek perjanjian dan mengatur khusus untuk itu.

Ketentuan bahwa perjanjian tidak boleh bertentangan dengan UU menunjukkan bahwa sekalipun perjanjian mengikat sebagai UU bagi para pihak, akan tetapi isi/materi perjanjian itu sendiri tidak boleh bertentangan dengan UU. ${ }^{14}$ Dengan demikian isi perjanjian yang dibuat para pihak harus mengacu pada keadilan, kebiasaan, atau undang-undang, bukan hanya kehendak dari kedua belah pihak an sich.

\section{Pengaturan Gaji Dosen Swasta menurut UU Guru dan Dosen}

Gajipenghasilan dosen termasuk salah satu hak dengan ketentuan penghasilan yang diperoleh di atas kebutuhan hidup minimum ${ }^{15}$ dan hak atas jaminan kesejahteraan sosial. Gaji tersebut terdiri dari:

a. gaji pokok;

b. tunjangan yang melekat pada gaji;

c. serta penghasilan lain yang berupa tunjangan profesi, tunjangan fungsional, tunjangan khusus, tunjangan kehormatan, serta maslahat tambahan yang terkaitdengan tugas sebagai dosen yang ditetapkan dengan prinsip penghargaan atas dasar prestasi.

Ketentuan mengenai gaji dosen swasta khususnya didasarkan pada perjanjian kejja atau kesepakatan kerja bersama, sehingga hal ini berbeda dengan ketentuan yang mengatur gaji dosen negeri yang secara tegas didasarkan pada peraturan perundang-undangan. Walaupun demikian, ada beberapa bagian dari gaji dosen swasta yang diberikan oleh pemerintah, yaitu:

1. Tunjangan profesi, yaitu diberikan kepada dosen yang telah memiliki sertifikat pendidik.

2. Subsidi tunjangan fungsional.

3. Tunjangan khusus, yaitu diberikan kepada dosen yang bertugas di daerah khusus.

4. Tunjangan kehormatan kepada profesor. Ketentuan tersebut juga menunjukkan bahwa bagian lain dari gaji dosen swasta harus ditanggung oleh satuan pendidikan tinggi yang terkait, yaitu gaji pokok, ${ }^{16}$ tunjangan melekat pada gaji, ${ }_{17}$ sebagian atau seluruh tunjangan fungsional, dan maslahat tambahan. ${ }^{18}$

${ }^{13}$ Pasal 1337 KUHPdt: Suatu sebab adalah terlarang, jika sebab itu dilarang oleh undang-undang atau bila sebab itu bertentangan dengan kesusilaan atau dengan ketertiban umum.

${ }^{14}$ Lihat juga ketentuan Pasal 1339 KUHPdt: Persetujuan tidak hanya mengikat apa yang tegas ditentukan di dalamnya, melainkan juga segala sesuatu yang menunut sifatnya persetujuan dituntut berdasarkan keadilan, kebiasaan, atau undang-undang.

${ }^{15}$ Yang dimaksud dengan penghasilan di atas kebutuhan hidup minimum adalah pendapatan yang cukup untukmemenuhi kebutuhan hidup dosen dan keluarganya secara wajar, baik sandang, pangan, papan, kesehatan, pendidikan, rekreasi, dan jaminan hari tua. Lihat Penjelasan Pasal 51 ayat (1) huruf a UU Guru dan Dosen.

${ }^{16}$ Adalah satuan penghasilan yang ditetapkan berdasarkan pangkat, golongan, dan masa keja. Lihat Penjelasan Pasal 52 ayat (1) UU Guru dan Dosen.

${ }^{17}$ Adalah tambahan penghasilan sebagai komponen kesejahteraan yang ditentukan berdasarkan jumlah tanggungan keluarga. Ibid.

${ }^{18}$ Adalah tambahan kesejahteraan yang diperoleh dalam bentuk asuransi, pelayanan kesehatan, atau bentuk kesejahteraan lain. Ibid. 
Terhadap gaji dosen swasta yang harus ditanggung oleh satuan pendidikan tinggi, ternyata pemerintah tidak begitu saja lepas tangan, yaitu dengan adanya ketentuan yang menegaskan bahwa "Pemerintah dan/atau pemerintah daerah menjamin terwujudnya maslahat tambahan" dan "Ketentuan lebih lanjut mengenai maslahat tambahan diatur dengan Peraturan Pemerintah". ${ }^{19}$

Besar kecilnya gaji yang diperoleh dosen tentunya juga diukur dari kewajiban-kewajiban yang harus dilakukan dosen, yaitu:

a. melaksanakan pendidikan, penelitian, dan pengabdian kepada masyarakat;

b. merencanakan, melaksanakan proses pembelajaran, serta menilai dan mengevaluasi hasil pembelajaran;

c. meningkatkan dan mengembangkan kualifikasi akademik dan kompetensi secara berkelanjutan sejalan dengan perkembangan ilmu pengetahuan, teknologi, dan seni;

d. bertindak objektif dan tidak diskriminatif atas dasar pertimbangan jenis kelamin, agama, suku, ras, kondisi fisik tertentu, atau latar belakang sosioekonomi peserta didik dalam pembelajaran;

e. menjunjung tinggi peraturan perundangundangan, hukum dan kode etik, serta nilai-nilai agama dan etika; dan

f. memelihara dan memupuk persatuan dan kesatuan bangsa.

Kewajiban-kewajiban yang dilakukan seorang dosen tersebut di atas apabila akan dijadikan tolok ukur untuk memberikan besaran gaji dosen, maka hal ini akan sangat sulit karena sifat dari kewajiban-kewajiban tersebut umum dan abstrak. Untuk itu, dibutuhkan adanya suatu standar yang jelas tentang besaran minimum bagi gaji dosen sesuai dengan kewajiban-kewajiban tersebut di atas. Apalagi, di samping pengaturan mengenai kewajiban-kewajiban tersebut tidak hanya menyangkut besaran gaji yang seharusnya diterima seorang dosen, juga menyangkut pelaksanaan tugas dosen yang berkonsekuensi pada pelaksanaan perjanjian kerja/kesepakatan kerja bersama yang telah disepakati para pihak.

Hak-hak yang menjadi imbal balik dari kewajiban dosen, adalah:

a. memperoleh penghasilan $\mathrm{di}$ atas kebutuhan hidup minimum dan jaminan kesejahteraan sosial;

b. mendapat promosi dan penghargaan sesuai dengan tugas dan prestasi kerja;

c. memperoleh perlindungan dalam melaksanakan tugas dan hak atas kekayaan intelektual;

d. memperoleh kesempatan untuk meningkatkan kompetensi, akses sumber belajar, informasi, sarana dan prasarana pembelajaran, serta penelitian dan pengabdian kepada masyarakat;

e. memiliki kebebasan akademik, mimbar akademik, dan otonomi keilmuan; dan

f. memiliki kebebasan dalam memberikan penilaian dan menentukan kelulusan peserta didik; dan

g. memiliki kebebasan untuk berserikat dalam organisasi profesi/organisasi profesi keilmuan.

Pengaturan mengenai hak dan kewajiban dosen seharusnya dijelaskan lebih lanjut dalam perjanjian kerja/kesepakatan kerja bersama yang dibuat oleh kedua belah pihak.

\footnotetext{
${ }^{19}$ Pasal 57 ayat (3) dan (4) UU Guru dan Dosen.
} 
Rincian lebih lanjut dari hak dan kewajiban para pihak sangat dibutuhkan guna pengukuran lebih lanjut untuk menentukan kapan, apa dan bagaimana salah satu pihak dianggap ingkar janil/wan prestatie, karena hal ini berkaitan dengan sanksi yang harus diatur secara tegas dalam perjanjian kerjal kesepakatan kerja bersama untuk melindungi kedua pihak. $^{20}$

\section{Pertindungan terhadap Gaji Dosen Swasta berdasarkan UU Guru dan Dosens}

Perlindungan terhadap dosen dalam pelaksanaan tugasnya, tidak hanya meliputi perlindungan hukum, juga perlindungan profesi, serta perlindungan keselamatan dan kesehatan kerja. ${ }^{2 \uparrow}$

Perlindungan hukum mencakup perlindungan terhadap tindak kekerasan, ancaman, perlakuan diskriminatif, intimidasi, atau perlakuan tidak adil dari peserta didik, orang tua peserta didik, masyarakat, birokrasi, dan/atau pihak lain.2

Perlindungan profesi mencakup perlindungan terhadap pelaksanaan tugas dosen sebagai tenaga profesional yang meliputi pemutusan hubungan kerja yang tidak sesuai dengan peraturan perundangundangan, pemberian imbalan yang tidak wajar, pembatasan kebebasan akademik, mimbar akademik, dan otonomi keilmuan, serta pembatasan/pelarangan lain yang dapat menghambat dosen dalam pelaksanaan tugas. 23

Perlindungan keselamatan dan kesehatan kerja meliputi perlindungan terhadap resiko gangguan keamanan kerja, kecelakaan kerja, kebakaran pada waktu kerja, bencana alam, kesehatan lingkungan kerja, dan/atau resiko lain. ${ }^{24}$

Perlindungan pertama, perlindungan hukum terhadap gaji dosen swasta adalah menyangkut kesepakatan antara para pihak yang dicapai dengan prinsip "nondiskriminasi", kesukarelaan (tanpa kekerasan, ancaman, paksaan) dan adil/keseimbangan.

Kesepakatan mengenai gaji dosen swasta yang diperoleh melalui perjanjian kerja/kesepakatan kerja bersama haruslah didasarkan pada prinsip non-diskriminasi, kesukarelaan dan keadilan bagi para pihak. Hal ini tentu harus juga sesuai dengan hak dan kewajiban yang dimiliki oleh para pihak, sehingga kejelasan tentang hak dan kewajiban para pihak perlu diperinci dalam perjanjian kerja/kesepakatan kerja bersama yang mereka buat. Contoh konkrit pengaturan mengenai waktu kerja dosen yang dapat dibuat dengan kuantitas tertentu adalah "SKS wajib bagi seorang dosen $=12$ SKS yang setara dengan jam kerja 36 jam per minggu",

${ }^{20}$ Pasal 78 ayat (3) UU Guru dan Dosen, bahwa "dosen yang diangkat oleh penyelenggara pendidikan atau satuan pendidikan tinggi yang diselenggarakan oleh masyarakat yang tidak menjalankan kewajiban sebagaimana dimaksud dalam Pasal 60 dikenai sanksi sesuai dengan perjanjian kerja atau kesepakatan kerja bersama".

${ }^{21}$ Pasal 75 ayat (1) UU Guru dan Dosen.

22 Pasal 75 ayat (3) UU Guru dan Dosen.

${ }_{23}$ Pasal 75 ayat (4) UU Guru dan Dosen.

${ }^{24}$ Pasal 75 ayat (5) UU Guru dan Dosen. 
sehingga seorang dosen yang mengajar lebih dari 12 SKS berhak atas tambahan gaji sedangkan yang mengajar kurang dari 12 SKS wajib berkantor untuk memenuhi kekurangan waktu kerja itu.

Prinsip non-diskriminasi, kesukarelaan dan keadilan harus didukung secara keseluruhan dalam pengaturan kepegawaian di satuan pendidikan tinggi yang bersangkutan, yaitu pengaturan sejak awal penerimaan dosen, pengangkatan, pengaturan jabatan akademik, penggajian, sampai pemutusan hubungan kerja atau pensiun.

Perlindungan kedua, perlindungan profesi yang dapat diberikan terkait dengan gaji yang diterima oleh dosen swasta dapat diberikan berdasarkan status dan kedudukan dosen sebagai seorang profesional, bukan sebagai seorang pekerja, walaupun istilah yang digunakan dalam UU Guru dan Dosen untuk perjanjian yang dibuat antara dosen dan satuan pendidikan tinggi adalah perjanjian kerja/kesepakatan kerja bersama.

Istilah perjanjian kerja atau kesepakatan kerja bersama/KKB di dalam UU Guru dan Dosen ternyata mempunyai satu pengertian, yaitu perjanjian tertulis antara guru atau dosen dengan penyelenggara pendidikan atau satuan pendidikan yang memuat syarat-syarat kerja serta hak dan kewajiban para pihak dengan prinsip kesetaraan dan kesejawatan berdasarkan peraturan perundang-undangan.

Subjek dalam perjanjian kerja atau KKB tersebut adalah dosen dan pemilik/pemimpin satuan pendidikan tinggi. Hal ini memunculkan pertanyaan mendasar "apakah hubungan yang muncul antara dosen dan pemilik/pemimpin satuan pendidikan tinggi tersebut termasuk dalam hubungan kerja yang didasarkan pada perjanjian kerja?" Apabila jawabannya adalah "ya", maka status dan kedudukan dosen adalah sebagai "pekerja" bukan sebagai "profesional"

Pengertian ini tentu saja tidak terlepas dari istilah "dosen" dalam UU Guru dan Dosen yang berarti adalah "pendidik profesional dan ilmuwan dengan tugas utama mentransformasikan, mengembangkan, dan menyebar-luaskan ilmu pengetahuan, teknologi, dan seni melalui pendidikan, penelitian dan pengabdian masyarakat".

"Pekerjaan" dosen dalam mentransformasikan, mengembangkan dan menyebar-luaskan ilmu pengetahuan, teknologi, dan seni melalui pendidikan, penelitian dan pengabdian masyarakat tersebut di atas, tidak dapat diperinci sedemikian rupa sehingga dapat dijadikan sebagai suatu objek perjanjian kerja sebagaimana dalam suatu hubungan kerja. Bahkan terutama terkait dengan sifat hubungan kerja yang ditegaskan dengan sifat "hubungan diperatas" (dienstverhouding), bukan hubungan yang didasarkan pada kesetaraan dan kesejawatan.

Dalam hubungan kerja, perintah/petunjuk dari pengusaha kepada pekerja/buruhnya harus ditaati dan tidak ada kebebasan bagi pihak pekerja untuk menyimpangi petunjukl perintah itu. Bahkan apabila pekerja/buruh menyimpang dari perintah/petunjuk pengusaha, maka ini dapat dijadikan dasar sebagai alasan adanya ingkar janji/ wanprestatie.

Lebih lanjut hal tersebut juga menunjukkan bahwa dosen bukan hanya seorang pekerja yang terlibat dalam suatu hubungan kerja dan harus tunduk pada perintah/petunjuk majikan/pengusahanya. Dosen adalah suatu profesi yang dalam. 
melaksanakan tugas keprofesionalannya sehingga dosen tidak hanya berhak atas gajil penghasilan, juga memilki hak-hak lain untuk mendukung kebebasannya, terutama adalah hak:

a. Memperoleh perlindungan dalam melaksanakan tugas dan hak atas kekayaan intelektual;

b. memperoleh kesempatan untuk meningkatkan kompetensi, akses sumber belajar, informasi, sarana dan prasarana pembelajaran, serta penelitian dan pengabdian kepada masyarakat.

c. memiliki kebebasan akademik, mimbar akademik, dan otonomi keilmuan;

d. memiliki kebebasan dalam memberikan penilaian dan menentukan kelulusan peserta didik.

Dengan adanya hak-hak dosen sébagaimana diatur dalam UU Guru dan Dosen, maka Dosen tidak hanya berhak atas gaji pokok, akan tetapi juga berhak atas tunjangan-tunjangan lain yang terkait dengan profesionalitas kerja dosen.

Dosen sebagai suatu profesi menunjukkan pula bahwa dalam melaksanakan tugas dan kewajibannya, dosen mempunyai kebebasan yang cukup besar dalam usaha semaksimal mungkin untuk mencapai suatu tujuan tertentu. Dasar dari pelaksanaan kewajiban dosen adalah usaha sungguh-sungguh, bukan hanya melaksanakan pekerjaan sesuai perintah/ petunjuk pimpinan atau bahkan dari mahasiswa sebagai konsumen/customer. Namun demikian dapat diatur mengenai tolok ukur tertentu bagi seorang dosen untuk melakukan kewajibannya dengan usaha sungguh-sungguh tersebut, terutama untuk menjaga profesionalitasnya, baik melalui kualifikasi, kompetensi, sertifikasi dan jabatan akademik.

Kualifikasi, kompetensi, sertifikasi dan jabatan akademik dosen secara umum diatur dalam UU Guru dan Dosen, sedangkan secara khusus pihak satuan pendidikan tinggi dapat mengatur tersendiri sesuai dengan peraturan perundang-undangan yang berlaku. Dengan demikian walaupun satuan pendidikan tingg̀i mempunyai kebebasan untuk mengatur secara khusus tentang kualifikasi, kompetensi, sertifikasi dan jabatan akademik dosen, akan tetapi aturan dari satuan pendidikan tinggi tidak boleh bertentangan dengan peraturan perundang-undangan.

Pengakuan profesi dosen juga diatur dalam UU Nomor 20 Tahun 2003 Tentang Sistem Pendidikan Nasional/Sisdiknas yang menyatakan bahwa pendidik merupakan tenaga profesional. ${ }^{25}$ Kedudukan guru dan dosen sebagai tenaga profesional mempunyai visi terwujudnya penyelenggaraan pembelajaran sesuai dengan prinsip-prinsip profesionalitas untuk memenuhi hak yang sama bagi setiap warga negara dalam memperoleh pendidikan yang bermutu. ${ }^{26}$

Perlindungan ketiga yang diberikan oleh UU Guru dan Dosen adalah perlindungan keselamatan dan kesehatan kerja yang dikaitkan dengan gaji dosen menunjukkan adanya bentuk lain dari gaji dosen yang tidak hanya berbentuk uang atau barang, akan tetapi juga gaji yang berbentuk jasa.

Gaji yang berbentuk jasa dalam UU Guru dan Dosen adalah gaji yang menyangkut

\footnotetext{
${ }^{25}$ Pasal 39 ayat (2) UU Sisdiknas.

${ }^{26}$ Penjelasan umum UU Guru dan Dosen.
} 
maslahat tambahan yang dapat diperoleh dosen dalam bentuk tunjangan pendidikan, asuransi pendidikan, beasiswa, dan penghargaan bagi dosen, serta kemudahan untuk memperoleh pendidikan bagi putra dan putri dosen, pelayanan kesehatan, atau bentuk kesejahteraan lain. ${ }^{27}$ Terwujudnya maslahat tambahan ini dijamin oleh pemerintah dan/ atau pemerintah daerah melalui peraturan pemerintah. ${ }^{28}$

Dosen yang diangkat oleh satuan pendidikan tinggi swasta berhak memperoleh jaminan sosial tenaga kerja sesuai dengan peraturan perundang-undangan, ${ }^{29}$ yang dalam hal ini adalah UU Nomor 3 Tahun 1992 Tentang Jaminan Sosial Tenaga Kerjal Jamsostek.

UU Jamsostek merupakan UU yang mengatur tentang jaminan sosial bagi tenaga kerja, yanng adạa di dalam atau di luar hubungan kerja. Ruang lingkup program jamsostek adalah:

a. Jaminan Kecelakaan Kerja;

b. Jaminan Kematian;

c. Jaminan Hari Tua;

d. Jaminan Pemeliharaan Kesehatan.

Dengan demikian perlindungan keselamatan dan kesehatan kerja bagi dosen swasta dapat berupa jasa-jasa yang tercakup dalam tunjangan-tunjangan sebagai bagian dari gaji, baik tunjangan melekat atau tunjangan lain.

\section{Simpulan}

Pengaturan gaji dosen yang didasarkan pada perjanjian kerja atau kesepakatan kerja bersama antara dosen swasta dan satuan pendidikan tinggi pada dasarnya tetap mengacu pada peraturan perundangundangan, sehingga campur tangan pemerintah masih cukup besar dalam hubungan antara para pihak.

Perlindungan terhadap gaji dosen swasta menurut UU Guru dan Dosen terdiri dari 3 (tiga) perlindungan, yaitu perlindungan hukum, perlindungan profesi, serta perlindungan keselamatan dan kesehatan kerja.

\section{Daftar Pustaka}

Utrecht, E., Pengantar Hukum Tata Usaha Negara Indonesia, Penerbitan dạn Balai Buku Indonesia, Jakarta, 1957.

Fred Ameln, Kapita Selekta Hukum Kedokteran, Cetakan Pertama, Grafikatama Jaya, Jakarta, 1991.

Iman Soepomo, Pengantar Hukum Perburuhan, Cetakan kesebelas (edisi revisi), Djambatan, Jakarta, 1995.

SF.,Marbun, Peradilan Administrasi Negara dan Upaya Administrasi di Indonesia, Liberty, Yogyakarta, 1997.

Sri Soemantri, Bunga Rampai Hukum Tata Negara Indonesia, Alumni, Bandung, 1992.

\footnotetext{
${ }^{27}$ Pasal 57 ayat (1) UU Guru dan Dosen.

${ }^{28}$ Pasal 57 ayat (2) dan (3) UU Guru dan Dosen.

${ }^{29}$ Pasal 58 UU Guru dan Dosen.
} 
Kitab Undang-undang Hukum Perdata Undang-undang Nomor 20 Tahun 2003 (KUHPdt). Tentang Sistem Pendidikan Nasional. Undang-undang Nomor 14 Tahun 1992 Undang-undang Nomor 14 Tahun 2005 Tentang Jaminan Sosial Tenaga Kerja. Tentang Guru dan Dosen. 